\title{
Auxin-Induced Resistance to Common Scab Disease of Potato Linked to Inhibition of Thaxtomin A Toxicity
}

\author{
Robert S. Tegg, Warwick M. Gill, and Hannah K. Thompson, Tasmanian Institute of Agricultural Research, \\ University of Tasmania, New Town Research Laboratories, 13 St. John's Avenue, New Town, Tasmania 7008, Aus- \\ tralia; Noel W. Davies, Central Science Laboratory, University of Tasmania, Private Bag 74, Hobart, Tasmania 7001, \\ Australia; John J. Ross, School of Plant Science, University of Tasmania, Private Bag 55, Hobart, Tasmania 7001, \\ Australia; and Calum R. Wilson, Tasmanian Institute of Agricultural Research, University of Tasmania, New Town \\ Research Laboratories, 13 St. John's Avenue, New Town, Tasmania 7008, Australia
}

\begin{abstract}
Tegg, R. S., Gill, W. M., Thompson, H. K., Davies, N. W., Ross, J. J., and Wilson, C. R. 2008. Auxin-induced resistance to common scab disease of potato linked to inhibition of thaxtomin A toxicity. Plant Dis. 92:1321-1328.

Production of the phytotoxin thaxtomin A by pathogenic Streptomyces spp. is essential for induction of common scab disease in potato. Prior studies have shown that foliar application of sublethal concentrations of 2,4-dichlorophenoxyacetic acid (2,4-D) and other auxin or auxin-like compounds significantly reduced severity and occurrence of common scab in subsequently produced tubers. However, the means of disease suppression by these compounds was not known. We confirm the disease suppressive activity of 2,4-D. Detailed tuber physiological examination showed that lenticel numbers, lenticel external dimensions, and periderm thickness and structure, physiological features believed to be critical to Streptomyces scabiei infection, were not substantially changed by $2,4-\mathrm{D}$ treatments, negating a possible mechanism for disease suppression through alteration of these structures. In contrast, our studies show accumulation of 2,4-D in tubers of treated plants occurs and is associated with an enhanced tolerance to thaxtomin A. Applying 2,4-D to cultures of S. scabiei did not significantly alter in vitro growth of the pathogen. Thaxtomin A production by the pathogen was inhibited by $2,4-\mathrm{D}$, but only at the highest rate tested $(1.0 \mathrm{mM})$, which is at least 200 -fold more than is found in 2,4-D treated tubers. These data suggest 2,4-D has no direct effect on the pathogen or its virulence. Confirmatory evidence from studies with Arabidopsis thaliana seedlings demonstrated that the auxins 2,4-D and IAA ameliorate thaxtomin A toxicity. The evidence presented whereby auxin treatment inhibits toxicity of thaxtomin A secreted by the pathogen suggests a novel indirect means of disease suppression.
\end{abstract}

Common scab disease of potato, induced by infection of expanding potato tubers by pathogenic Streptomyces spp., is of economic importance worldwide $(25,26)$. Within the Australian potato industry, annual losses of up to $4 \%$ of the industry's value have been attributed to this disease in recent years, mainly through rejected seed and/or increased processing costs (42). Central to pathogenicity is the pathogen's production of the phytotoxin thaxtomin A, a modified dipeptide molecule that appears to inhibit cellulose biosynthesis $(17,20,25,26)$.

Various strategies are employed to minimize losses due to common scab disease, but no one strategy consistently provides economically effective disease suppression (26). A series of trials conducted

Corresponding author: Calum R. Wilson E-mail: Calum.Wilson@dpiw.tas.gov.au

Accepted for publication 16 May 2008.

doi:10.1094/PDIS-92-9-1321

(C) 2008 The American Phytopathological Society in the United Kingdom demonstrated that foliar application of auxins or certain auxin analogues on potatoes significantly reduced common scab disease development (28-31). Glasshouse trials showed that foliar sprays of synthetic auxins 2,4dichlorophenoxyacetic acid (2,4-D) and 3,5-dichlorophenoxyacetic acid (3,5-D) reduced disease by 50 and $90 \%$, respectively, when sprayed at or just before tuber initiation (29,31). However, associated disadvantages of using 2,4-D and 3,5-D included decreased yields, increased numbers of small tubers, and an increased proportion of deformed tubers (29). Field trials with 3,5-D resulted in disease reduction of only $30 \%$ and significant decreases in yield and mean tuber weight, discouraging the commercial development of these treatments for common scab control (30). Benzoic acids, including 5-chloro-2nitrobenzoic acid (CNB), were later identified as also possessing significant (but lesser) disease inhibiting activity with minimal impact on yield, tuber number, and distortion (28).

Chemical-induced disease resistance has been demonstrated in a range of different plant-pathogen systems, but of particular interest are the phenomena of herbicideinduced disease resistance and/or indolerelated compounds (including auxins) that induce resistance. Studies undertaken so far have identified that, at the concentrations used to induce resistance, the herbicides or indole compounds have no apparent toxicity to the disease-causing organisms, suggesting that protection results from activation of indirect mechanisms $(6,9,10$, 14,36,38). These mechanisms include physiological and anatomical changes (9), but in many cases are unknown (36).

Consistent with the aforementioned studies, McIntosh et al. $(28,29)$ demonstrated through in vitro trials that the auxin sources, at the rates applied, neither directly inhibit nor severely disrupt growth of the pathogen, Streptomyces scabiei. McIntosh et al. $(28,29)$ suggested that the protective effect induced by these auxin sprays was due to their ability to modify the response of the host to the infection, so that scab symptoms did not develop. Work by Burrell (7) also suggested a modification of host metabolism, as potato disks treated with auxin showed reduced browning (phenolic metabolism) when inoculated with $S$. scabiei. While the mechanism of disease suppression was not investigated, this work $(28,29)$ provided clues to the success of auxin-based treatments, as they were only effective at key physiological stages, just before and during early tuber development, suggesting a protective effect. Rapid tuber expansion and morphological changes in the putative pathogen entry sites, such as stomata transformation into lenticels, occur at this time (2).

Lenticels are natural openings in the tuber periderm used for gas exchange (40), with immature lenticels representing the key entry sites into tubers for S. scabiei $(18,19)$. However, there is also evidence that both $S$. ipomoeae and S. scabiei hyphae can directly penetrate the tuber periderm and infect potato tissue $(8,25)$. In potatoes, cultivars resistant to certain tuber diseases have been characterized as having low lenticel density, more cell layers in the periderm, and intensive cuticularization in lenticel tissues $(27,39,43)$. Auxin effects on the morphological development of len- 
ticels or periderm during early tuber growth, a period of susceptibility to infection by $S$. scabiei $(2,4)$, might help explain how auxin treatments confer protection against common scab disease. Furthermore, recent evidence from our laboratory suggests an interaction whereby increased sensitivity to auxin correlates with an increased sensitivity to thaxtomin A (37).

This work investigates possible mechanisms of common scab disease suppression by examining the impact of auxin $(2,4-\mathrm{D})$ on lenticel development and gross periderm structure. We tested the theory that 2,4-D may alter tuber sensitivity to thaxtomin A toxicity, and we further examined the effect of auxins 2,4-D and IAA on thaxtomin toxicity in other plant systems. We also evaluated possible influences of 2,4-D treatment on pathogen growth and thaxtomin A production.

\section{MATERIALS AND METHODS}

Pathogen culture and plant establishment. Pathogenic S. scabiei strain G\#32 was initially isolated in 1990 from a common scab diseased potato tuber from the northwest coast of Tasmania, Australia. Inoculum was prepared by suspending spores harvested from a 2-week-old culture grown on ISP2 medium (35) in $5 \mathrm{ml}$ of sterile water, and adding this to a sterilized mixture of $100 \mathrm{~g}$ of vermiculite and $500 \mathrm{ml}$ of SAY solution (20 g sucrose, 1.2 g L-asparagine, $0.6 \mathrm{~g} \mathrm{~K}_{2} \mathrm{HPO}_{4}$, and $10 \mathrm{~g}$ yeast extract per liter, $\mathrm{pH}$ 7.2). Inoculum was incubated at $24^{\circ} \mathrm{C}$ in the dark for 14 days, whereupon profuse sporulation was observed.

Plastic pots $(25 \mathrm{~cm}$ diameter, $30 \mathrm{~cm}$ high) were filled with a potting mix containing sand, peat, and composted pine bark (10:10:80, pH 6.0) premixed with Osmocote 16-3.5-10 NPK resin coated fertilizer (Scotts Australia Pty Ltd.) at the rate of $6 \mathrm{~kg} / \mathrm{m}^{3}$. In trials where pathogen amendments were included, a 3-cm-deep, $15-\mathrm{cm}$-wide band (approximately $10 \mathrm{~g}$ ) of inoculum was mixed in the surface and covered by an additional $5 \mathrm{~cm}$ of potting mix. Potato plants (Solanum tuberosum cv. Russet Burbank) were derived from single node tissue-culture cuttings placed in a semisolid (0.8\% agar) MS medium (32) amended with $3 \%$ sucrose, $0.05 \%$ casein hydrolysate, and $0.004 \%$ ascorbic acid, $\mathrm{pH}$ 5.8. At 2 weeks of age, plants were transplanted into the pots ( 1 plant per pot) and hand-watered for the first week. For the remainder of the experiment, all pots were watered once every second day with approximately $5 \mathrm{ml}$ delivered to each pot. This regime allowed the potting mix to dry substantially between waterings. Additional plants were grown alongside the trial to allow tuber initiation to be periodically monitored without disturbing the trial plants. All trials were undertaken within a glasshouse environment with temperatures maintained at $22 \pm 2{ }^{\circ} \mathrm{C}$. A soluble fertilizer was applied monthly (Miracle-Gro Water Soluble all purpose plant food, 15-13.112.4 NPK, Scotts Australia Pty Ltd.).

Spray treatments. All spray treatments were timed to coincide with the reported critical infection period, which occurs 2 to 6 weeks after tuber initiation (ati) $(18,19)$. This was determined by periodically observing tuber formation in the additional plants. The single spray (s) was applied 14 days ati, double spray (d) at 14 and 24 days ati, and triple spray (t) at 14, 24, and 34 days ati. Spray treatments were a fine mist applied to leaves until runoff. Absorbent cotton towels were placed on the soil surface during spraying to ensure that soil was protected from direct spray contact, and towels were removed immediately after treatment.

Unless otherwise specified, spray treatments included water controls, single or multiple treatments of $2,4-\mathrm{D}$ at $0.90 \mathrm{mM}$ $(0.20 \mathrm{~g} /$ liter $)$, and single or multiple treatments of CNB at $1.60 \mathrm{mM}(0.32 \mathrm{~g} /$ liter $)$. These compounds and rates were chosen based on prior published results $(28,29,31)$ and the novel interest in the modes of action of these compounds. All spray treatments, including controls, contained $0.2 \%$ ethanol (for dissolution of the auxins) and $0.5 \mathrm{~g} /$ liter Tween 80 (wetting agent).

Pot trial design and treatments. The effects of foliar auxin sprays on tuber and scab development were studied in five pot trials in 2003, 2004, 2005, and 2007. Treatments and experimental design within each trial were tailored and altered year-to-year based on the outcomes of the previous trials.

In pot trial 1 , five separate spray treatments were tested: a water control, 2,4-D (s), 2,4-D (t), CNB (s), and CNB (t). All pots were amended with pathogen inoculum and treatments were replicated $(n=6)$ in a randomized block design (30 pots in total). The first foliar spray was applied on 7 April 2003, and all tubers were harvested 8 weeks later at senescence and scored for disease and tuber yield.

Pot trial 2 included two spray treatments: control, and 2,4-D (t), applied to pots with and without pathogen inoculum. Two tubers were harvested from each of five plants $(n=5)$ from each treatment immediately before the first spray, at 1, 2, and 4 weeks after first treatment, and at senescence (i.e., five harvest dates). Treatments were arranged in a randomized split-split plot design (100 pots in total). Harvested tubers from non-pathogenamended pots were placed in $70 \%$ ethanol and stored at $4{ }^{\circ} \mathrm{C}$ for later sectioning and microscopic examination of periderm and lenticular structures. Pots were returned to the trial and grown through to harvest. The first foliar spray was applied on 5 April 2004, and all remaining tubers were harvested 8 weeks later (senescence) and assessed for disease and tuber yield.

In pot trial 3, there were two spray treatments: control, and 2,4-D (t), with no pots receiving pathogen inoculum. Four plants $(n=4)$ from each of the two treatments were harvested immediately prior to the first auxin foliar spray (control), and then at 1,2,3, and 4 weeks after the initial spray treatment (i.e., five harvest dates). Treatments were arranged in a randomized split plot design (40 pots in total). Three tubers per pot at each harvest were assessed for lenticel number, dimensions, and sensitivity to thaxtomin A on tuber slices. The first foliar spray was applied on 10 March 2005.

In pot trial 4, there were two spray treatments: control, and 2,4-D (d), with no pots receiving pathogen inoculum. There was one harvest assessment made, 2 weeks after the initial spray treatment. Treatments were replicated $(n=5)$ in a randomized block design (10 pots in total). Tubers were assessed for sensitivity to thaxtomin A by application to tuber slices, and 2,4-D levels in tubers were quantified. The first foliar spray was made on 10 May 2005 .

In pot trial 5, there were five spray treatments: control, and 2,4-D (s) applied at four rates, $0.23,0.45,0.90$, and 1.81 $\mathrm{mM}$. There were two harvest assessments made at 2 and 6 weeks after the first treatment spray with treatments replicated $(n=$ 5 ) in a randomized block design (20 pots in total). Quantification of 2,4-D levels in tubers and the sensitivity of tuber slices to thaxtomin A-induced necrosis were assessed at both harvest dates. The first foliar spray was applied on 11 May 2007.

Disease and tuber yield assessment (pot trials 1 and 2). After plants had fully senesced, tubers were harvested, rinsed gently under cold running water, and airdried. The number and individual weight of each tuber per pot was recorded. Tubers weighing more than $2.0 \mathrm{~g}$ were assessed for disease. The surface area covered by disease lesions and the deepest lesion on each tuber were estimated using the method described in Wilson (41).

Tuber physiological assessments (pot trials 2 and 3). Tissue blocks approximately $50 \mathrm{~mm}^{3}$ were cut from selected tubers from 2,4-D treated and control plants in pot trial 2, then fixed, sectioned, and stained as described by Pinkard et al. (33). Sections were examined with a Leica DMLB (Type LB 30T) compound microscope (Leica Microsystems, Wetzlar $\mathrm{GmbH}$, Germany), noting periderm thickness, number of cell layers, and lenticular development.

Furthermore, three representative tubers from each pot in pot trial 3 were sampled, the number of visible lenticels on each tuber counted, and the external dimensions of lenticels measured. The maximum length (L) and width (W) of 15 individual randomly selected lenticels per tuber were recorded, five each from the stolon end, the mid-section, and the rose end.

Extraction and quantification of 2,4-D levels from potato tubers (pot trials 4 
and 5). Methods to extract and quantify free 2,4-D levels from tubers were developed based on a modification of the methods used for indole-3-acetic acid (IAA) analyses from various plant tissues (34). Harvested tubers were cut into 1-cm cubes (including skin tissue), and $10 \mathrm{~g}$ of tuber tissue was immediately immersed in cold $\left(-20^{\circ} \mathrm{C}\right) 80 \%$ methanol containing butylated hydroxytoluene (Sigma, 250 $\mathrm{mg} / \mathrm{liter}$ ). Samples were stored for 1 to 2 weeks at $-20^{\circ} \mathrm{C}$. Samples were then homogenized using a blender and left overnight at $4^{\circ} \mathrm{C}$, after which insoluble material was removed by filtration (Whatman No. 1, Whatman Int., Maidstone, UK). Based on preliminary trial extractions, $90 \mathrm{ng}$ of a 2,4-D internal standard $\left(\left[{ }^{13} \mathrm{C}_{6}\right] 2,4-\mathrm{D}, 100\right.$ $\mathrm{ng} / \mu \mathrm{l}$ in acetone, Catalog no. XA11940 200AC, Dr. Ehrenstorfer Laboratories, Augsburg, Germany) was then added to a 2- to 8-ml aliquot of the filtrate.

Extracts were then dried using a sample concentrator. A VacRC C18 Sep-Pak (Waters SA, Guyancourt, France) was preconditioned with $15 \mathrm{ml}$ of $100 \%$ methanol followed by $15 \mathrm{ml}$ of $0.4 \%$ acetic acid in distilled water. The dried samples were transferred in three aliquots of 2-ml washes of $0.4 \%$ acetic acid to the VacRC. 2,4-D was eluted from the Sep-Pak using $15 \mathrm{ml}$ of methanol in $0.4 \%$ acetic acid, directly into a McCartney bottle. After samples were reduced to dryness, $200 \mu \mathrm{l}$ of $100 \%$ methanol and $750 \mu \mathrm{l}$ of diazomethane were added, and the samples were vortexed and dried under $\mathrm{N}_{2}$. One milliliter of distilled water was added to the samples, followed by the addition of three aliquots of $400 \mu$ l diethyl ether, with the ether fraction transferred to a collection vial after each addition. The pooled ether fraction was dried under $\mathrm{N}_{2}$, and $40 \mu \mathrm{l}$ of chloroform was added for analysis by selected reaction monitoring gas chromatography-mass spectrometry (GC-MS).

The samples were analyzed by GC-MS using tandem MS on a triple quadruple mass spectrometer in a manner analogous to that described by Jones et al. (16) for IAA. The oven temperature was held at $50^{\circ} \mathrm{C}$ for $2 \mathrm{~min}$, then ramped to 190 at $30^{\circ} \mathrm{C} \mathrm{min}{ }^{-1}$, then to $220^{\circ} \mathrm{C}$ at $10^{\circ} \mathrm{C} \mathrm{min}^{-1}$, then to $270^{\circ} \mathrm{C}$ at $30^{\circ} \mathrm{C} \mathrm{min}{ }^{-1}$ with a final hold time of $4 \mathrm{~min}$. The transfer line temperature was $280^{\circ} \mathrm{C}$, and the ion source was at $220^{\circ} \mathrm{C}$. The MS was operated in selected reaction monitoring mode, with a precursor peak width of $5 \mathrm{~m} / \mathrm{z}$, units to isolate the whole chlorine cluster, and a product ion peak width of $1.2 \mathrm{~m} / \mathrm{z}$ units. Collision gas was argon and the collision energy was $-8 \mathrm{~V}$. For 2,4-D methyl ester, the selected precursor ion (in MS1) was $\mathrm{m} / \mathrm{z}, 234$ and the selected product ions (in MS3) were $m / z, 199$ and 201. For ${ }^{13} \mathrm{C}_{6} 2,4-$ D methyl ester, the ions were $\mathrm{m} / \mathrm{z}, 240$ (MS1) and $m / z, 205$ and 207 (MS3). The amount of 2,4-D methyl ester was calculated from the sum of the peak areas of unlabeled product ions relative to that of the ${ }^{13} \mathrm{C}_{6} 2$ 2,4-D methyl ester.

Sensitivity of tubers to thaxtomin A using a tuber slice assay (pot trials 3, 4, and 5). At each sequential assessment, three typical tubers were selected from each pot and tested for thaxtomin A sensitivity using a modification of the method described by Acuña et al. (1). Whole tubers were surface-sterilized with $0.5 \%$ sodium hypochlorite for $10 \mathrm{~min}$ and air-dried before being cut into 0.5 -cm-thick slices and placed in 90-mm petri dishes with moist sterile filter paper (Whatman No. 1). Filter paper disks of $6 \mathrm{~mm}$ diameter (Whatman No. 1) were immersed in thaxtomin $A$ solution $(57 \mu \mathrm{M}$ for pot trials 3 and 4 , and $7 \mu \mathrm{M}$ for pot trial 5 , all dissolved in $5 \%$ acetone) for $1 \mathrm{~h}$, air-dried, and placed on the potato slices (one to three disks per slice), with disks immersed in 5\% acetone solution and air-dried used as controls. After placement on the potato slices, $10 \mu \mathrm{l}$ of sterile distilled water was applied to each disk (1) to ensure stable contact between tuber and disk. Plates were incubated at $24^{\circ} \mathrm{C}$ in the dark and evaluated after 7 days (by the same individual in all trials) for necrosis in the defined area under the filter paper disk: $0=$ no necrosis, $0.5=$ very sparse flecks, $1=$ few light brown flecks, $1.5=$ few dark brown flecks, $2=$ light brown flecks in circle, $2.5=$ dark brown flecks in circle, $3=$ light brown necrosis, $3.5=$ dark brown necrosis, and 4 $=$ black necrosis.

Pathogen growth and toxin production in response to 2,4-D. Spore solutions of S. scabiei strains G\#32 (pathogenic, thaxtomin A producing) and G\#10 (nonpathogenic, non-thaxtomin A-producing) were prepared by scraping the surface of four well sporulating plates into $20 \mathrm{ml}$ of water. The spore solutions were further diluted $1 / 100$ in water, and $0.1-\mathrm{ml}$ aliquots were streaked onto oatmeal agar: ISP3 (35) plates amended with either 0.0 (control),
$0.1,1.0,10,100$, or $1,000 \mu \mathrm{M} 2,4-\mathrm{D}$ and incubated in darkness at $30^{\circ} \mathrm{C}$. There were five replicates of each strain and 2,4-D treatment. After 3 weeks, colony numbers per plate were counted.

To examine the effect of 2,4-D treatments on thaxtomin A production by the pathogen, $5 \mathrm{~g}$ of agar was excised (in approximately $10 \mathrm{~mm}^{2}$ pieces) from each replicate plate (both strains) and placed into a 15-ml Falcon tube. Chloroform (1 $\mathrm{ml}$ ) was added and tubes vortexed, gently agitated for $1 \mathrm{~h}$, and centrifuged, with the chloroform fraction then transferred into a collection tube. This chloroform extraction was repeated, giving a total of $2 \mathrm{ml}$ of chloroform extract, which was reduced to dryness, and the exudate (containing thaxtomin A) resuspended in $2.0 \mathrm{ml}$ of methanol for determination of thaxtomin A content.

Furthermore, the strains G\#32 and G\#10 were also grown in $500 \mathrm{ml}$ of oatmeal liquid broth (24) in 1-liter Erlenmeyer flasks amended with the same 2,4-D treatments and controls. Each treatment was replicated three times with flasks incubated on a shaker $(160 \mathrm{rpm})$ in darkness at $30^{\circ} \mathrm{C}$. After 3 weeks, thaxtomin A was extracted and concentrated in chloroform, as described by Loria et al. (24), and thaxtomin A content was determined.

Thaxtomin A determination. All samples were analyzed by HPLC-UV and HPLC-MS in series. Where sample content was adequate, quantitation was based on the LC-UV data; for samples where the UV response was too weak (almost exclusively the agar plate extracts), quantitation was done by LC-MS, which had a much lower LOQ. The HPLC was a Waters Alliance 2690 HPLC fitted with a 996 PhotoDiodeArray (PDA) detector. The column was a Waters Novapak C-18 $150 \times 3.9 \mathrm{~mm}$

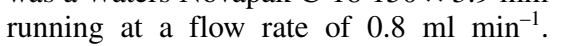
Solvent A was methanol, solvent B was $2 \%$ acetic acid in water. The gradient was

Table 1. Effect of the auxins 2,4-dichlorophenoxyacetic acid (2,4-D) and indole-3-acetic acid (IAA) on seedling death and chlorosis of excised stem tissues of Arabidopsis thaliana cv. Columbia induced by thaxtomin $\mathrm{A}$

\begin{tabular}{|c|c|c|c|c|c|}
\hline \multicolumn{3}{|c|}{ Seedlings } & \multicolumn{3}{|c|}{ Excised stem tissues } \\
\hline $\begin{array}{c}\text { Thaxtomin A } \\
(\mu \mathrm{M})\end{array}$ & $\begin{array}{l}2,4-D \\
(\mu \mathrm{M})\end{array}$ & $\begin{array}{c}\text { Death }^{a} \\
(\%)\end{array}$ & $\begin{array}{c}\text { Thaxtomin A } \\
(\mu \mathrm{M})\end{array}$ & $\begin{array}{r}\text { IAA } \\
(\boldsymbol{\mu M} \mathbf{M})\end{array}$ & $\begin{array}{c}\text { Chlorosis }^{\mathbf{b}} \\
(\%)\end{array}$ \\
\hline 0.1 & 0 & 100 & 0.1 & 0 & 65.5 \\
\hline 0.1 & 0.1 & $75.0 * \mathrm{c}$ & 0.1 & 0.01 & 87.5 \\
\hline 0.1 & 0.2 & $52.5^{*}$ & 0.1 & 0.1 & 47.1 \\
\hline \multirow[t]{2}{*}{0.1} & 1.0 & $72.5^{*}$ & 0.1 & 1.0 & $13.3 *$ \\
\hline & & $P<0.001$ & & & $P<0.001$ \\
\hline 0 & 0 & 0 & 0 & 0 & 0 \\
\hline 0 & 0.1 & 0 & 0 & 0.01 & 0 \\
\hline 0 & 0.2 & 0 & 0 & 0.1 & 0 \\
\hline 0 & 1.0 & 0 & 0 & 1.0 & 0 \\
\hline
\end{tabular}

a Percentage of $A$. thaliana seedlings lacking evidence of growth after 25 days on treatment medium.

b Percentage of stem segments excised from 5-day-old A. thaliana seedlings exhibiting chlorosis after 7 days on treatment media.

$\mathrm{c} *=$ Sample sets which showed significantly $(P<0.01)$ less seedling death or chlorosis than the thaxtomin A treatment without auxin amendment when using the chi-squared test of equal proportions with a Bonferroni correction. 
$45 \% \mathrm{~A}: 55 \% \mathrm{~B}$ to $60 \% \mathrm{~A}: 40 \% \mathrm{~B}$ at $7 \mathrm{~min}$, then a direct ramp to $95 \% \mathrm{~A}: 5 \% \mathrm{~B}$ and held there till $12 \mathrm{~min}$ to flush the column. Reequilibration time between samples was 3 min. The PDA was monitored between 250 and $500 \mathrm{~nm}$, and a 400-nm chromatogram was extracted from this. The retention time of thaxtomin A under these conditions was $5.1 \mathrm{~min}$. The response was externally calibrated from injection of known amounts of a thaxtomin A standard. HPLC-MS was carried out on a Finnigan LCQ Classic in positive ion atmospheric pressure ionization mode. The source current was $5 \mu \mathrm{A}$, the vaporizer temperature was $430^{\circ} \mathrm{C}$, the heated capillary temperature was $170^{\circ} \mathrm{C}$, and the capillary voltage was $30 \mathrm{~V}$. Solvent flow was diverted until $4.5 \mathrm{~min}$, and diversion resumed at $8 \mathrm{~min}$. Selected reaction monitoring was used to quantify thaxtomin $\mathrm{A}$; the $[\mathrm{M}+\mathrm{H}]^{+}$ion at $\mathrm{m} / \mathrm{z}, 439$ was isolated (width $4 \mathrm{~m} / \mathrm{z}$ units), activated with a colli- sion energy of $20 \%$, and product ions between $\mathrm{m} / \mathrm{z}, 400$ to $\mathrm{m} / \mathrm{z}, 430$ scanned out. Chromatograms were generated from the sum of $\mathrm{m} / \mathrm{z}, 408$ and $\mathrm{m} / \mathrm{z}, 421$ product ions, and the area of the peak at $5.1 \mathrm{~min}$ was measured. An external calibration was run every fifth sample and the adjusted response factor used for quantitation.

Inhibition of thaxtomin A-induced chlorosis and seedling death by auxin treatments. Arabidopsis thaliana cv. Columbia seedlings were grown under conditions previously described (37). In the first experiment, seed (40 per treatment) were surface-sterilized and placed onto the surface of plates of MS medium amended with $0.1 \mu \mathrm{M}$ thaxtomin A with or without 2,4-D $(0.1,0.2$, or $1.0 \mu \mathrm{M})$ treatments. They were incubated for a period of 25 days in a growth chamber (temperature $22^{\circ} \pm 1^{\circ} \mathrm{C}$ and 16-h day length $\left.\left[60 \mu \mathrm{mol} \cdot \mathrm{m}^{-2} \cdot \mathrm{s}^{-1}\right]\right)$, after which the death of emergent seed-

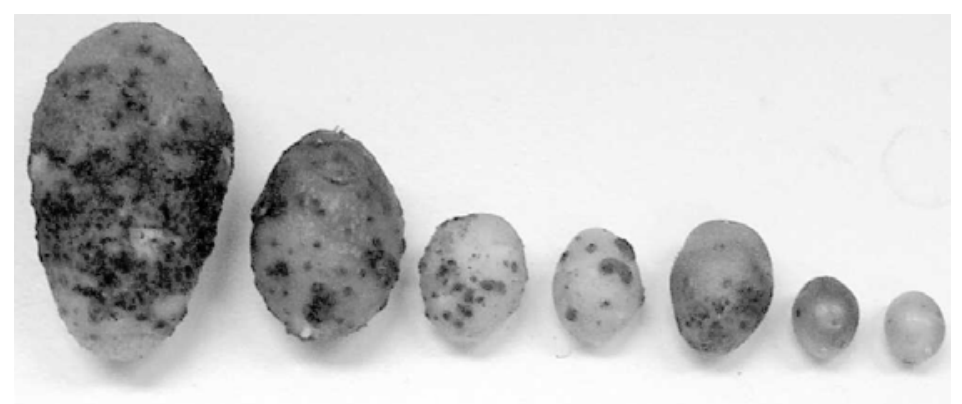

(i)

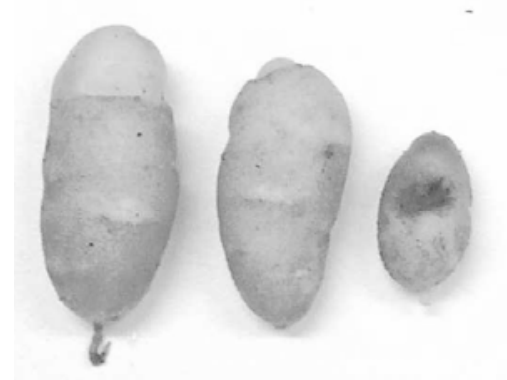

(ii)

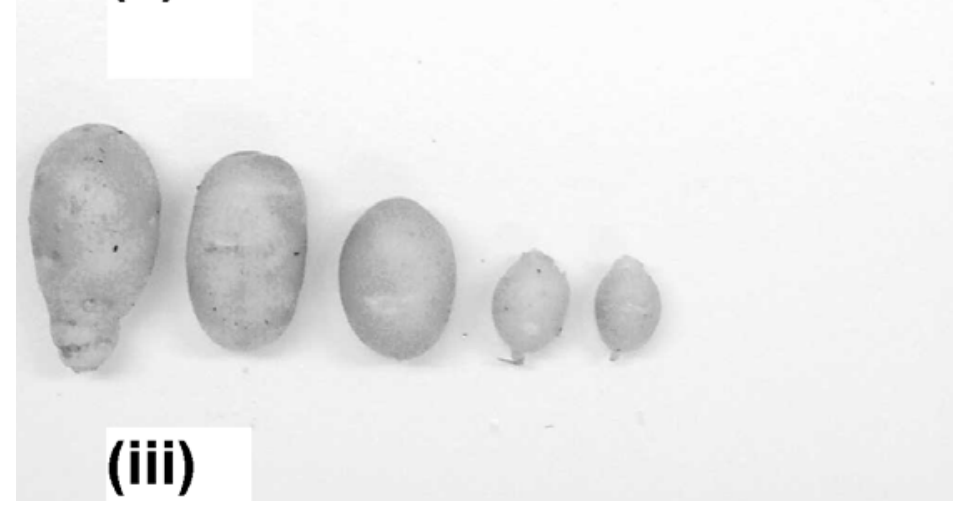

Fig. 1. Russet Burbank tubers grown in soil amended with Streptomyces scabiei strain G\#32 and treated with 2,4-dichlorophenoxyacetic acid (2,4-D) foliar sprays. Spray treatments included (i) no 2,4-D, (ii) 2,4-D single spray, and (iii) 2,4-D three sequential sprays at $0.90 \mathrm{mM}$. Initial sprays were made 14 days after tuber initiation, and subsequent sprays at 10-day intervals.

lings (cessation of growth and associated bleaching) was recorded. In the second experiment, A. thaliana cv. Columbia seedlings were grown for 5 days on unamended MS medium before excision of stem segments (15 to 29 per treatment) lacking apical meristems (to remove major sources of endogenously produced IAA). These were plated onto MS medium amended with thaxtomin $\mathrm{A}(0.1 \mu \mathrm{M})$ with or without IAA $(0.01,0.1$, or $1.0 \mu \mathrm{M})$ treatments. After 5 days incubation in a growth chamber, chlorosis (distinct loss of color and bleaching compared to the untreated control), or no chlorosis (no discernible difference compared to the control) was scored.

Data analysis. Where comparisons of two percentage data sets were required (Table 1), a two sample binomial chisquare test of equal proportions was used with the Bonferroni correction. All other data were subjected to analysis of variance using Genstat 9 (Rothamsted Experimental Station, Harpenden, Hertfordshire, UK). Significance was calculated at either $P=$ 0.05 or $P=0.01$ as noted, and least significant difference (LSD) was used for comparison of treatment means. All data were tested for normality and homogeneity of variance, and where appropriate, $\log$ or square-root transformation was used.

\section{RESULTS}

Disease and agronomic performance. In pot trial 1, water-treated control tubers had substantial common scab disease, while those treated with 2,4-D showed negligible disease symptoms (Fig. 1). Common scab surface coverage $(\%)$ of plants receiving both single and triple 2,4D treatments was significantly reduced $(P$ $<0.05$ ) in comparison to the control (Table 2). Treatment with $2,4-\mathrm{D}$ did not significantly affect mean greatest lesion depth, mean tuber weight, and the number of tubers/plant, although there was a trend suggesting reduced lesion depth and tuber weight. Disease surface coverage, lesion depth, and tuber yield of CNB (s) and (t) treated plants did not significantly vary from the water control (Table 2).

In pot trial 2, a similar disease suppressive effect of 2,4-D (t) treatment was shown (Table 2). In this trial, both common scab tuber surface coverage and lesion depth were significantly reduced $(P<$ $0.05)$ with the application of 2,4-D (t) compared to the water control (Table 2). While the number of tubers per plant and mean weight of individual tubers were not affected significantly by treatment, the total weight of potatoes per plant was significantly reduced $(P<0.05)$ with the application of 2,4-D (t).

Tuber physiological responses: Periderm and lenticular development. Microscopic examination of tuber samples from pot trial 2 showed no discernible differences in periderm and lenticular 
morphology between water control tubers and those from 2,4-D treated plants (data not presented). In both cases, early tuber development (tubers 1 to 3 weeks of age) was characterized by a thin periderm layer with layer numbers increasing with age. While lenticel development was generally not seen in tuber tissue of 1 to 2 weeks of age, by 3 weeks of age lenticular activity was sometimes evident. Similarly, as tubers from both 2,4-D treated and nontreated plants aged (from 4 to 6 weeks), there were no differences in observed cell density characteristic of meristematic activity and lenticular development within the phellogen.

Lenticel number and dimensions. Foliar sprays of 2,4-D had no significant effect $(P>0.05)$ on mean lenticel numbers per tuber, which increased in both 2,4-D treated and nontreated plants in pot trial 3 from approximately 70 to 120 per tuber over the 3-week assessment period (data not presented).

Foliar sprays of 2,4-D had an occasional minor but significant effect $(P<0.05)$ on lenticel dimensions, most evident at the midsection of the tuber where mean lenticel width was reduced by up to $10 \%$ (Table 3 ). As the size of the tuber increased (week 1 through week 4 after first spray), external lenticel dimensions generally increased (Table 3).

Quantification of 2,4-D levels from tubers. In trial 4, tubers harvested 2 weeks after the first of two foliar 2,4-D sprays (4 days following the second) had $992 \mathrm{ng}$ 2,4$\mathrm{D} / \mathrm{g}$ tuber fresh weight (TFW), while tubers from the water-treated plants contained trace levels (20 ng 2,4-D/g TFW), which were approximately 50-fold less than in tubers from treated plants. In pot trial 5, tubers harvested from plants treated with $0.23,0.45,0.90$, and $1.81 \mathrm{mM} 2,4-\mathrm{D}$ as a single foliar spray had an average of 255, 236, 463, and $381 \mathrm{ng}$ 2,4-D/g TFW 2 weeks after treatment and 193, 243, 304, and $206 \mathrm{ng}$ 2,4-D/g TFW 6 weeks after treatment, respectively. Tubers from the water-treated plants contained an average of 71 and $39 \mathrm{ng} 2,4-\mathrm{D} / \mathrm{g}$ tuber FW at the two harvest dates, four- to eight-fold less than in tubers from treated plants. The residual amount recorded from watertreated tubers may be attributable to minor spray drift.

Sensitivity of tubers to thaxtomin A using a tuber slice assay. Across all three pot trials (3, 4, and 5), significant decreases $(P<0.05)$ in thaxtomin A-induced necrosis scores were recorded for tubers harvested from plants treated with 0.90 $\mathrm{mM}$ 2,4-D (s, d, or t foliar sprays), compared to tubers from water control plants (Table 4, Fig. 2). In pot trial 3, decreases in necrosis score of 30.9, 3.2, 28.1, and $26.7 \%$ were recorded in the weekly harvests, 1 to 4 weeks following the first of three 2,4-D foliar treatments. In trial 4, a $21.3 \%$ reduction was shown 2 weeks after the first of two 2,4-D sprays. In pot trial 5, reductions of $46.2,57.3,50.4$, and $53.4 \%$ were recorded 2 weeks following, and $39.0,47.6,33.7$, and $66.3 \% 6$ weeks following single-spray treatments of 0.23 , $0.45,0.90$, and $1.81 \mathrm{mM}$ 2,4-D (Table 4).

Pathogen growth and toxin production in response to 2,4-D. Pathogen sur-

Table 2. Impact of 5-chloro-2-nitrobenzoic acid (CNB) and 2,4-dichlorophenoxyacetic acid (2,4-D) foliar sprays on common scab disease and tuber properties of cv. Russet Burbank inoculated with Streptomyces scabiei strain G\#32

\begin{tabular}{|c|c|c|c|c|c|c|}
\hline Pot trial & Treatment $^{\mathrm{a}}$ & $\begin{array}{l}\text { Disease surface } \\
\text { coverage }(\%)^{\mathbf{b}, \mathrm{c}}\end{array}$ & $\begin{array}{l}\text { Lesion depth } \\
\text { score }(0-3)^{b, c}\end{array}$ & $\begin{array}{c}\text { No. of } \\
\text { tubers/plant }\end{array}$ & $\begin{array}{c}\text { Total tuber } \\
\text { weight/plant }(g)^{\mathrm{c}}\end{array}$ & $\begin{array}{l}\text { Mean tuber } \\
\text { weight }(\mathrm{g})^{\mathrm{c}}\end{array}$ \\
\hline 1 & $\begin{array}{l}\text { Water (t) } \\
\text { CNB (s) } \\
\text { CNB (t) } \\
2,4-\mathrm{D}(\mathrm{s}) \\
2,4-\mathrm{D}(\mathrm{t}) \\
P \\
\operatorname{LSD}(0.05)\end{array}$ & $\begin{array}{c}30.0 \mathrm{a} \\
40.5 \mathrm{a} \\
27.8 \mathrm{a} \\
3.8 \mathrm{~b} \\
2.2 \mathrm{~b} \\
0.003 \\
21.4\end{array}$ & $\begin{array}{l}1.26 \mathrm{ab} \\
1.82 \mathrm{a} \\
1.18 \mathrm{ab} \\
0.81 \mathrm{~b} \\
0.50 \mathrm{~b} \\
0.034 \\
0.83\end{array}$ & $\begin{array}{l}3.8 \\
3.2 \\
2.8 \\
2.7 \\
4.0 \\
0.508 \\
\text { ns }\end{array}$ & $\begin{array}{l}24.9 \mathrm{ab} \\
32.6 \mathrm{a} \\
17.1 \mathrm{ab} \\
13.0 \mathrm{~b} \\
14.9 \mathrm{~b} \\
0.198 \\
17.04\end{array}$ & $\begin{array}{l}8.8 \\
11.1 \\
6.0 \\
4.9 \\
5.1 \\
0.326 \\
\text { ns }\end{array}$ \\
\hline 2 & $\begin{array}{l}\text { Water }(\mathrm{t}) \\
2,4-\mathrm{D}(\mathrm{t}) \\
P \\
\operatorname{LSD}(0.05)\end{array}$ & $\begin{array}{c}24.1 \mathrm{a} \\
5.6 \mathrm{~b} \\
<0.001 \\
4.5\end{array}$ & $\begin{array}{c}2.15 \mathrm{a} \\
0.93 \mathrm{~b} \\
<0.001 \\
0.27\end{array}$ & $\begin{array}{l}9.64 \\
8.48 \\
0.062 \\
\text { ns }\end{array}$ & $\begin{array}{c}190.7 \mathrm{a} \\
164.5 \mathrm{~b} \\
0.015 \\
21.9\end{array}$ & $\begin{array}{l}22.55 \\
19.55 \\
0.063 \\
\mathrm{~ns}\end{array}$ \\
\hline
\end{tabular}

${ }^{a}$ Spray treatments included single (s) or triple ( $\mathrm{t}$ ) sequential sprays of $0.32 \mathrm{~g} /$ liter CNB or $0.2 \mathrm{~g} / \mathrm{liter} 2,4-\mathrm{D}$, or a control water treatment with initial applications made 14 days after tuber initiation, and subsequent applications at 10-day intervals.

${ }^{\mathrm{b}}$ Extent of disease surface coverage of tubers and lesion depth score was determined following the methods of Wilson (41).

${ }^{\mathrm{c}}$ Means followed by same letter within the same column are not significantly different at $P=0.05$ using Fisher's LSD test; ns $=$ nonsignificant.

Table 3. Effect of triple (t) 2,4-dichlorophenoxyacetic acid (2,4-D) foliar sprays on tuber lenticel dimensions ${ }^{\mathrm{a}}$

\begin{tabular}{|c|c|c|c|c|c|c|c|c|c|}
\hline \multirow{4}{*}{$\begin{array}{l}\text { Location } \\
\text { on tuber }\end{array}$} & \multirow[b]{4}{*}{ Treatment } & \multicolumn{8}{|c|}{ Lenticel dimensions $(\mu \mathrm{m})^{\mathrm{b}}$} \\
\hline & & \multicolumn{8}{|c|}{ Weeks after first foliar spray } \\
\hline & & \multicolumn{2}{|c|}{1} & \multicolumn{2}{|c|}{2} & \multicolumn{2}{|c|}{3} & \multicolumn{2}{|c|}{4} \\
\hline & & $\mathbf{L}$ & $\mathbf{W}$ & $\mathbf{L}$ & $\mathbf{W}$ & $\mathbf{L}$ & $\mathbf{W}$ & $\mathbf{L}$ & $\mathbf{W}$ \\
\hline Stolon end & $\begin{array}{l}\text { Water }(\mathrm{t}) \\
2,4-\mathrm{D}(\mathrm{t}) \\
P \\
\operatorname{LSD}(0.05)\end{array}$ & $\begin{array}{l}415 \\
406 \\
0.614 \\
\text { ns }\end{array}$ & $\begin{array}{c}358 \\
326 \\
0.120 \\
\mathrm{~ns}\end{array}$ & $\begin{array}{c}478 \\
465 \\
0.493 \\
\text { ns }\end{array}$ & $\begin{array}{l}409 \\
418 \\
0.615 \\
\mathrm{~ns}\end{array}$ & $\begin{array}{c}485 \\
478 \\
0.684 \\
\text { ns }\end{array}$ & $\begin{array}{c}418 \\
416 \\
0.927 \\
\mathrm{~ns}\end{array}$ & $\begin{array}{l}514 \\
491 \\
0.173 \\
\text { ns }\end{array}$ & $\begin{array}{l}448 \\
420 \\
0.052 \\
\mathrm{~ns}\end{array}$ \\
\hline Midsection & $\begin{array}{l}\text { Water }(\mathrm{t}) \\
2,4-\mathrm{D}(\mathrm{t}) \\
P \\
\operatorname{LSD}(0.05)\end{array}$ & $\begin{array}{c}525 \mathrm{a} \\
477 \mathrm{~b} \\
0.001 \\
24.1\end{array}$ & $\begin{array}{l}436 \mathrm{a} \\
372 \mathrm{~b} \\
<0.001 \\
23.5\end{array}$ & $\begin{array}{c}518 \\
515 \\
0.869 \\
\text { ns }\end{array}$ & $\begin{array}{l}439 \\
449 \\
0.619 \\
\mathrm{~ns}\end{array}$ & $\begin{array}{c}578 \\
564 \\
0.420 \\
\mathrm{~ns}\end{array}$ & $\begin{array}{c}475 \mathrm{a} \\
450 \mathrm{~b} \\
0.02 \\
20.2\end{array}$ & $\begin{array}{l}585 \\
573 \\
0.414 \\
\mathrm{~ns}\end{array}$ & $\begin{array}{c}503 \mathrm{a} \\
469 \mathrm{~b} \\
0.003 \\
19.1\end{array}$ \\
\hline Rose end & $\begin{array}{l}\text { Water }(\mathrm{t}) \\
2,4-\mathrm{D}(\mathrm{t}) \\
P \\
\operatorname{LSD}(0.05)\end{array}$ & $\begin{array}{l}400 \\
401 \\
0.926 \\
\text { ns }\end{array}$ & $\begin{array}{l}321 \\
319 \\
0.814 \\
\text { ns }\end{array}$ & $\begin{array}{c}448 \\
441 \\
0.639 \\
\text { ns }\end{array}$ & $\begin{array}{c}365 \\
360 \\
0.665 \\
\mathrm{~ns}\end{array}$ & $\begin{array}{c}494 \\
500 \\
0.672 \\
\text { ns }\end{array}$ & $\begin{array}{c}384 \\
410 \\
0.107 \\
\mathrm{~ns}\end{array}$ & $\begin{array}{l}529 \\
515 \\
0.133 \\
\text { ns }\end{array}$ & $\begin{array}{l}422 \\
406 \\
0.153 \\
\text { ns }\end{array}$ \\
\hline
\end{tabular}

a Initial 2,4-D sprays $(0.2 \mathrm{~g} /$ /iter $)$ were applied at 14 days after tuber initiation, and subsequent sprays $(0.2 \mathrm{~g} /$ liter $)$ at 10 -day intervals. Water-only sprays were included as controls. Measurements represent the mean maximum length (L) and width (W) of a lenticel from either the stolon end, midsection, or rose end of a tuber harvested at 1,2,3, and 4 weeks after first foliar spray.

${ }^{\mathrm{b}}$ Means followed by same letter within the same column are not significantly different at $P=0.05$ using Fisher's LSD test; ns $=$ nonsignificant. 
vival and growth as determined by colony numbers on plates receiving an aliquot of spore suspension diluted $1 / 100$ was not altered by the addition of $0.1 \mu \mathrm{M}$ to 1.0 $\mathrm{mM}$ 2,4-D to the growth medium (Table 5). Thaxtomin A production by the pathogen growing on both solid and liquid medium was not significantly altered with the addition of low to moderately high levels of 2,4-D (0.1 to $100 \mu \mathrm{M})$. However, under the greatest levels of 2,4-D tested (1.0 $\mathrm{mM}$ ), thaxtomin A production was significantly $(P<0.05)$ suppressed in three of the four trials (Table 5).

Inhibition of thaxtomin A-induced chlorosis and seedling death by auxin treatments. Cessation of growth and subsequent death of $A$. thaliana seedlings (at day 25) in the presence of $0.1 \mu \mathrm{M}$ thaxtomin A was significantly reduced when 0.1 to $1.0 \mu \mathrm{M} 2,4-\mathrm{D}$ was added to the medium (Table 1). Similarly, chlorosis induced by $0.1 \mu \mathrm{M}$ thaxtomin A was significantly less in the decapitated $A$. thaliana stems when $1.0 \mu \mathrm{M}$ (but not 0.01 to $0.1 \mu \mathrm{M}$ ) IAA was added to the medium (Table 1).

\section{DISCUSSION}

The suppression of common scab symptom development by foliar auxin sprays has been previously demonstrated in a series of glasshouse and field trials (2831). McIntosh et al. (29) had particular success with the phenoxyacetic acids 3,5$\mathrm{D}$ and 2,4-D, reducing scab disease by 90 and $50 \%$, respectively. Our glasshouse trials over two consecutive years (trials 1 and 2) using 2,4-D showed similar substantial disease suppression, with 80 to $90 \%$ reduction in scab surface coverage. However, the disease suppression McIntosh et al. (28) achieved with CNB (50\% scab surface reduction) was not found in our study (trial 1). The major benefit of using the di-substituted benzoic acids such as CNB was that yield and the shape of the tuber were not significantly affected (28), as was the case with the dichlorophenoxyacetic acids like 2,4-D $(30,31)$. In our trials, deformation in tuber shape was not obvious following 2,4-D application, but yields, although not significantly affected by the treatment, tended to be lower following 2,4-D treatment.

Lenticels are key entry points for several potato pathogens including those causing common scab, late blight (Phytophthora infestans), and bacterial soft rot (Erwinia carotovora; 3 ). Immature lenticels present during tuber elongation are suggested to represent the key physiological stage most susceptible to infection by the common scab pathogen $(18,19)$. There are, however, no reports relating lenticel density to common scab and few conclusive reports relating lenticel structure or size directly to common scab of potato. Reports that have related lenticel structure to common scab resistance have produced conflicting results $(2,11,23)$. Longrée (23) concluded that the shape and size of the surface of lenticels are unimportant in scab resistance; rather the compact (in resistant varieties) or loose (in susceptible varieties) nature of the complementary filling cells was critical. Darling (11) concluded that the size of lenticels was important, with larger lenticels associated with susceptible cultivars. Like Longrée (23), however, Darling (11) concluded the open or closed nature of the complementary cells reflected scab susceptibility. Adams (2) further contradicted and disputed both of these reports by noting no differences in lenticel formation between resistant and susceptible varieties. Further clarification
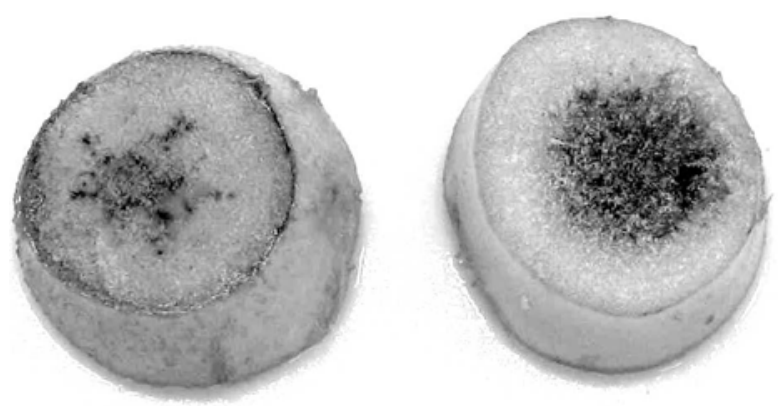

Fig. 2. Tuber slice assay for thaxtomin A tolerance. Typical necrotic lesions on tuber slices after 7 days exposure to $57 \mu \mathrm{M}$ thaxtomin A (pot trial 4). The tuber on the left was from a plant that received two spray treatments of $0.90 \mathrm{mM}$ 2,4-dichlorophenoxyacetic acid (2,4-D) (necrosis rating of 2.5); the tuber on the right was from an unsprayed control plant (necrosis rating of 3.5).

Table 4. Effect of 2,4-dichlorophenoxyacetic acid (2,4-D) foliar sprays on mean necrosis ratings from tuber slices exposed to $57 \mu \mathrm{M}$ thaxtomin A (pot trials 3 and 4$)$ and $7 \mu \mathrm{M}$ thaxtomin $\mathrm{A}\left(\right.$ pot trial 5) ${ }^{\mathrm{a}}$

\begin{tabular}{|c|c|c|c|c|c|c|c|c|c|}
\hline \multirow[b]{3}{*}{ Treatment } & \multicolumn{9}{|c|}{ Necrosis ratings from tuber slice assay ${ }^{b}$} \\
\hline & \multicolumn{4}{|c|}{ Pot trial $3^{c}$} & \multicolumn{2}{|c|}{ Pot trial $4^{c}$} & \multicolumn{3}{|c|}{ Pot trial $5^{c}$} \\
\hline & 1 & 2 & 3 & 4 & Treatment & 2 & Treatment & 2 & 6 \\
\hline Water (t) & $2.78 \mathrm{a}$ & $2.81 \mathrm{a}$ & $2.78 \mathrm{a}$ & $3.11 \mathrm{a}$ & Water (d) & $3.05 \mathrm{a}$ & Water (s) & $1.17 \mathrm{a}$ & $2.46 \mathrm{a}$ \\
\hline \multirow{4}{*}{$2,4-\mathrm{D}(\mathrm{t})$} & $1.92 \mathrm{~b}$ & $2.72 \mathrm{a}$ & $2.00 \mathrm{~b}$ & $2.28 \mathrm{~b}$ & $2,4-\mathrm{D}(\mathrm{d})$ & $2.40 \mathrm{~b}$ & $2,4-\mathrm{D}(\mathrm{s} ; 0.23 \mathrm{mM})$ & $0.63 \mathrm{~b}$ & $1.50 \mathrm{~b}$ \\
\hline & & & & & & & $2,4-\mathrm{D}(\mathrm{s} ; 0.45 \mathrm{mM})$ & $0.50 \mathrm{~b}$ & $1.29 \mathrm{bc}$ \\
\hline & & & & & & & 2,4-D (s; $0.90 \mathrm{mM})$ & $0.58 \mathrm{~b}$ & $1.63 \mathrm{~b}$ \\
\hline & & & & & & & $2,4-\mathrm{D}(\mathrm{s} ; 1.81 \mathrm{mM})$ & $0.54 \mathrm{~b}$ & $0.83 \mathrm{c}$ \\
\hline$P$ & $<0.001$ & 0.688 & 0.003 & $<0.001$ & & 0.012 & & 0.038 & $<0.001$ \\
\hline $\operatorname{LSD}(0.05)$ & 0.344 & $\mathrm{~ns}$ & 0.500 & 0.329 & & 0.498 & & 0.470 & 0.579 \\
\hline
\end{tabular}

${ }^{a}$ Spray treatments included water control sprays or single $(\mathrm{s} ; 1 \times 0.23-1.81 \mathrm{mM})$, double $(\mathrm{d} ; 2 \times 0.90 \mathrm{mM})$, or triple $(\mathrm{t} ; 3 \times 0.90 \mathrm{mM}) 2,4-\mathrm{D}$ sprays, with initial sprays made at 14 days after tuber initiation, and subsequent sprays made at 10-day intervals.

${ }^{\text {b }}$ Means followed by same letter within the same column are not significantly different at $P=0.01$ using Fisher's LSD test; ns $=$ nonsignificant

${ }^{\mathrm{c}}$ Sampling times in weeks. 
there are rare exceptions where $S$. ipomoeae and $S$. scabiei hyphae have been shown to penetrate the tuber $(8,25)$, implying the periderm may perhaps play a minor role in common scab resistance.

In contrast to the negligible effect of 2,4-D on key tuber physiological structures, pot trials 3,4 , and 5 show that thaxtomin A toxicity in tubers was significantly ameliorated following 2,4-D treatment. The accumulation of 2,4-D within tuber tissues was associated with reduced toxicity of thaxtomin A. These findings were further supported by the studies with $A$. thaliana seedlings whereby the presence of either 2,4-D or IAA within the culture medium ameliorated the toxic effects (seedling death or tissue chlorosis) of thaxtomin A. The study with IAA supplement further suggested that the effect may be dosage dependent, as only the greatest rate was effective in significantly reducing thaxtomin A toxicity. This may represent a reduced efficiency of pathogen invasion and disease development, as thaxtomin A aids this penetration from cell to cell $(24,25)$. Indirect evidence (7) supports these findings with application of auxin to potato disks reducing tuber browning when inoculated with $S$. scabiei. It is highly probable that this observation represents auxin interacting with thaxtomin A (secreted by S. scabiei) inhibiting tuber browning. Furthermore, recently reported evidence whereby a thaxtomin A-auxin interaction was postulated using an auxin-sensitive $A$. thaliana mutant (37) provides further weight to the findings in this study.

We confirmed the results of McIntosh et al. $(28,29)$ demonstrating that 2,4-D (at every concentration tested) has no effect on pathogen survival or growth, and add to this observation by showing 2,4-D does not affect the ability of the pathogen to produce thaxtomin A, except at the highest rate $(1.0 \mathrm{mM})$ tested. While this rate corresponds to the standard treatment rate of 2,4-D applied to the foliage, it is 200-fold greater than the amount present in tubers following treatment to which the pathogen may be exposed. Thus, we believe that any effect of 2,4-D on thaxtomin synthesis is negligible.
Within the common scab pathosystem, 2,4-D appears to induce disease resistance. The direct applicability of auxin foliar sprays for commercial potato production in the UK was questioned due to a decreased observed efficacy of the treatments in the field, associated tuber defects and yield penalties, and the fact that adequate control was achieved employing careful irrigation scheduling. However, we suspect difficulties associated with achieving adequate protection in the field may relate to synchronization of plant emergence (and thus the critical period of disease induction), making optimal timing of treatments difficult. Also, within Australia and many other parts of the world, adequate water for common scab management is often unavailable or overly expensive. We suggest a foliar spray treatment that can significantly reduce common scab disease would still be highly beneficial, particularly if used in conjunction with other management strategies such as resistant cultivars. The reduced rates of 2,4-D appeared to provide similar suppression of thaxtomin A toxicity, suggesting that reduced treatment rates effective in disease suppression also may diminish possible negative impacts on tuber yield and quality. This warrants further study.

The level of 2,4-D accumulation in tubers appears to slowly decay with time (Table 1), but persists at efficacious concentrations for at least 6 weeks following treatment, suggesting there may be little benefit of multiple spray treatments. However, 2,4-D accumulation also poses a potential threat to the commercial use of this disease management strategy if levels in harvested tubers exceed maximum tolerated residue limits. Further detailed study of 2,4-D persistence in tubers over a full growing period (and storage) would be necessary to ensure residue compliance.

The above studies provide evidence for a unique mechanism of action, whereby 2,4-D induces resistance to the toxin that $S$. scabiei produces. This work provides increased knowledge of the disease and suggests that opportunities exist to identify alternate materials or treatment rates that ameliorate thaxtomin A toxicity with minimal effects on tuber quality and yield and that may allow incorporation of an auxin foliar spray into an integrated disease management strategy for common scab. This mechanism of modality appears novel and at least within this pathosystem provides some insight into understanding the phenomenon of auxin-induced disease resistance. The mechanism of auxin inhibition of thaxtomin A toxicity is not determined. Thaxtomin A has been reported to induce programmed cell death (PCD) in exposed plant tissues (12). Recently, Gopalan (13) demonstrated PCD could be reversed by treatment with auxins 2,4-D and IAA. This represents one possible model for this interaction. It is also noteworthy that 2,4-D (and other auxins) share chemical similarities to the thaxtomin A molecule, and thus direct competition for a putative cellular binding site provides another possible mechanism.

\section{ACKNOWLEDGMENTS}

For assistance with statistical analyses, we thank D. Ratkowsky and R. Corkrey. This work was supported by a postgraduate scholarship award from the University of Tasmania and potato levy funding from Horticulture Australia Limited (HAL) in partnership with the Potato Processing Association of Australia. The Australian Government provides matched funding for all of HAL's R\&D activities. Part of the A. thaliana study was conducted in the laboratory of R. Loria, Cornell University.

\section{LITERATURE CITED}

1. Acuña, I. A., Strobel, G. A., Jacobsen, B., and Corsini, D. L. 2001. Glucosylation as a mechanism of resistance to thaxtomin A in potatoes. Plant Sci. 161:77-88.

2. Adams, M. J. 1975. Potato tuber lenticels: Development and structure. Ann. Appl. Biol. 79:265-273.

3. Adams, M. J. 1975. Potato tuber lenticels: Susceptibility to infection by Erwinia carotovora var. atroseptica and Phytophthora infestans. Ann. Appl. Biol. 79:275-282.

4. Adams, M. J., and Lapwood, D. H. 1978. Studies on the lenticel development, surface microflora and infection by common scab (Streptomyces scabies) of potato tubers growing in wet and dry soils. Ann. Appl. Biol. 90:335-343.

5. Bajit, G. B., and Gapasin, R. M. 1987. Relationship between morphological characteristics and varietal resistance of sweet potato to scab infection caused by Sphaceloma batatas Saw. Ann. Trop. Res. 9:75-83.

Table 5. Effect of 2,4-dichlorophenoxyacetic acid (2,4-D) treatments on growth of Streptomyces scabiei strain G\#32 and thaxtomin A (TxA) production after a 3-week incubation in darkness at $30^{\circ} \mathrm{C}$

\begin{tabular}{|c|c|c|c|c|c|c|}
\hline \multirow[b]{2}{*}{ Treatment } & \multicolumn{2}{|c|}{ Colony count $\left(10^{-2}\right.$ dilution $)$} & \multicolumn{2}{|c|}{$\begin{array}{c}\text { Tx A production on agar plates } \\
(\mu \mathrm{g} \text { TxA/5 g agar })^{\mathrm{a}}\end{array}$} & \multicolumn{2}{|c|}{$\begin{array}{l}\text { Tx A production in liquid culture } \\
(\mu \mathrm{g} \text { TxA/500 ml culture })^{\mathrm{a}}\end{array}$} \\
\hline & Trial 1 & Trial 2 & Trial 1 & Trial 2 & Trial 1 & Trial 2 \\
\hline No 2,4-D & 53 & 159 & $0.05(0.22) \mathrm{a}$ & $0.19(0.42) \mathrm{ab}$ & $95(1.46)$ & $318(2.24) \mathrm{a}$ \\
\hline $0.1 \mu \mathrm{M} 2,4-\mathrm{D}$ & 73 & 164 & $0.05(0.21) \mathrm{a}$ & $0.25(0.50) \mathrm{a}$ & $92(1.93)$ & $148(2.11) \mathrm{a}$ \\
\hline $1.0 \mu \mathrm{M} 2,4-\mathrm{D}$ & 79 & 168 & $0.05(0.21) \mathrm{a}$ & $0.15(0.38) \mathrm{b}$ & $71(1.84)$ & $161(2.18) \mathrm{a}$ \\
\hline $10 \mu \mathrm{M} 2,4-\mathrm{D}$ & 82 & 158 & $0.05(0.21) \mathrm{a}$ & $0.19(0.43) \mathrm{ab}$ & $182(2.25)$ & $158(2.12) \mathrm{a}$ \\
\hline $100 \mu \mathrm{M} 2,4-\mathrm{D}$ & 71 & 143 & $0.03(0.17) a b$ & $0.27(0.51) \mathrm{a}$ & $123(1.94)$ & $474(2.61) \mathrm{a}$ \\
\hline $1 \mathrm{mM}$ 2,4-D & 61 & 147 & $0.01(0.12) b$ & $0.01(0.13) \mathrm{c}$ & $61(1.01)$ & $14(1.01) \mathrm{b}$ \\
\hline$P$ & 0.15 & 0.41 & 0.034 & $<0.001$ & 0.359 & 0.012 \\
\hline LSD (0.05) & ns & ns & $(0.066)$ & $(0.096)$ & $\mathrm{ns}$ & $(0.73)$ \\
\hline
\end{tabular}

a Data are actual means and transformed means: square root (agar culture) and log (liquid culture) (in parentheses). Transformed means followed by same letter within the same column are not significantly different at $P=0.05$ using Fisher's LSD test; ns = nonsignificant. 
6. Bolter, C., Brammall, R. A., Cohen, R., and Lazarovits, G. 1993. Glutathione alterations in melon and tomato roots following treatment with chemicals which induce disease resistance to Fusarium wilt. Physiol. Mol. Plant Pathol. 42:321-336.

7. Burrell, M. M. 1984. Inhibition of browning, phenoxyacetic acids and phenolic metabolism in potato tuber discs: A model system to study chemicals that control common scab. Plant Pathol. 33:325-336.

8. Clark, C. A., and Matthews, S. W. 1987. Histopathology of sweet potato root infection by Streptomyces ipomoea. Phytopathology 77:1418-1423.

9. Cohen, R., Blaier, B., Schaffer, A. A., and Katan, J. 1996. Effect of acetochlor treatment on Fusarium wilt and sugar content in melon seedlings. Eur. J. Plant Pathol. 102:45-50.

10. Cohen, R., Yarden, O., Katan, J., Riov, J., and Lisker, N. 1987. Paclobutrazol and other plant growth-retarding chemicals increase resistance of melon seedlings to Fusarium wilt. Plant Pathol. 36:558-564

11. Darling, H. M. 1937. A study of scab resistance in the potato. J. Agric. Res. 54:305-317.

12. Duval, I., Brochu, V., Simard, M., Beaulieu, C., and Beaudoin, N. 2005. Thaxtomin A induces programmed cell death in Arabidopsis thaliana suspension-cultured cells. Planta 222:820-831.

13. Gopalan, S. 2007. Reversal of an immunity associated plant cell death program by the growth regulator auxin. Nature Precedings: doi: 10.1038/npre.2007.1347: Posted 18 Nov. 2007.

14. Grinstein, A., Lisker, N., Katan, J., and Eshel, Y. 1984. Herbicide-induced resistance to plant wilt diseases. Physiol. Plant Pathol. 24:347356.

15. Hooker, W. J., and Page, O. T. 1960. Relation of potato tuber growth and skin maturity to infection by common scab, Streptomyces scabies. Am. Potato J. 37:414-423.

16. Jones, S. E., Demeo, J. S., Davies, N. W., Noonan, S. E., and Ross, J. J. 2005. Stems of the Arabidopsis pin1-1 mutant are not deficient in free indole-3-acetic acid. Planta 222:530534.

17. King, R. R., Lawrence, C. H., Clark, M. C., and Calhoun, L. A. 1989. Isolation and characterisation of phytotoxins associated with Streptomyces scabies. J. Chem. Soc. - Chem. Commun. 13:849-850.

18. Lapwood, D. H., and Adams, M. J. 1973. The effect of a few days of rain on the distribution of common scab (Streptomyces scabies) on young potato tubers Ann. Appl. Biol.
73:277-283.

19. Lapwood, D. H., and Adams, M. J. 1975. Mechanisms of control of common scab by irrigation. Pages 123-129 in: Biology and Control of Soil Borne Pathogens. G. W. Bruehl, ed. American Phytopathological Society, St Paul, MN.

20. Lawrence, C. H., Clark, M. C., and King, R. R. 1990. Induction of common scab symptoms in aseptically cultured potato tubers by the vivotoxin, thaxtomin. Phytopathology 80:606608.

21. Li, G., Sheng, Y., Gao, Y., Li, X., Gao, S., Wang, J., and Sun, L. 2004. Study on the relationship between lenticel tissue structure and density and the occurrence of apple rough bark disease. J. Fruit Sci. 21:350-353.

22. Liu, H., Li, C., Fan, Y., and Hou, B. 2003. Host factors affecting resistance of apple fruit to ring rot of apple and analysis of their correlation. J. Agric. Univ. Hebei 26:56-60.

23. Longrée, K. 1931. Untersuchungen über die Ursache des verschiedenen Verhaltens der Kartoffelsorten gegen Schorf. Arbeiten Biologischen Bundesanstalt Land- Forstwirtschaft 19:285-336.

24. Loria, R., Bukhalid, R. A., Creath, R. A., Leiner, R. H., Olivier, M., and Steffens, J. C. 1995. Differential production of thaxtomins by pathogenic Streptomyces species in vitro. Phytopathology 85:537-541.

25. Loria, R., Coombs, J., Yoshida, M., Kers, J., and Bukhalid, R. 2003. A paucity of bacterial root diseases: Streptomyces succeeds where others fail. Physiol. Mol. Plant Pathol. 62:6572

26. Loria, R., Kers, J., and Joshi, M. 2006. Evolution of plant pathogenicity in Streptomyces. Annu. Rev. Phytopathol. 44:469-487.

27. Mahajan, M., Thind, T. S., and Dhillon, M. 2004. Studies on stem and tuber anatomical characteristics of potato cultivars in relation to resistance/susceptibility to late blight. Plant Dis. Res. (Ludhiana) 19:151-154.

28. McIntosh, A. H., Bateman, G. L., and Chamberlain, K. 1988. Substituted benzoic and picolinic acids as foliar sprays against potato common scab. Ann. Appl. Biol. 112:397-401.

29. McIntosh, A. H., Bateman, G. L., Chamberlain, K., Dawson, G. W., and Burrell, M. M. 1981. Decreased severity of potato common scab after foliar sprays of 3,5dichlorophenoxyacetic acid, a possible antipathogenic agent. Ann. Appl. Biol. 99:275281.

30. McIntosh, A. H., Burrell, M. M., and Hawkins, J. H. 1982. Field trials of foliar sprays of 3,5dichlorophenoxyacetic acid (3,5-D) against common scab on potatoes. Potato Res. 25:347350.

31. McIntosh, A. H., Chamberlain, K., and Dawson, G. W. 1985. Foliar sprays against potato common scab: Compounds related to 3,5dichlorophenoxyacetic acid. Crop Prot. 4:473480.

32. Murashige, T., and Skoog, F. 1962. A revised medium for rapid growth and bioassays with tobacco tissue cultures. Physiol. Plant. 15:473 497.

33. Pinkard, E, Gill, W, and Mohammed, C. 2006. Physiology and anatomy of lenticel-like structures on leaves of Eucalyptus nitens and Eucalyptus globulus seedlings. Tree Physiol. 26:989-999.

34. Ross, J. J., Reid, J. B., Swain, S. M., Hasan, O., Poole, A. T., Hedden, P., and Willis, C. L. 1995. Genetic regulation of gibberellin deactivation in Pisum. Plant J. 7:513-523.

35. Shirling, E. B., and Gottlieb, D. 1966. Methods for characterisation of Streptomyces species. Int. J. Syst. Bacteriol. 16:313-340.

36. Starratt, A. N., and Lazarovits, G. 1999. Herbicide-induced disease resistance and associated increases in free amino acid levels in melon plants. Can. J. Plant Pathol. 21:33-36.

37. Tegg, R. S., Melian, L., Wilson, C. R., and Shabala, S. 2005. Plant cell growth and ion flux responses to the streptomycete phytotoxin thaxtomin A: Calcium and hydrogen flux patterns revealed by the non-invasive MIFE technique. Plant Cell Physiol. 46:638-648.

38. Ueno, M., Kihara, J., Honda, Y., and Arase, S. 2004. Indole-related compounds induce the resistance to rice blast fungus, Magnaporthe grisea in barley. J. Phytopathol. 152:606-612.

39. Weber, J., and Bartel, W. 1986. Potato lenticels - Starting point and port of entry for wet rots. Kartoffelforschung Aktuell 1986:45-54.

40. Wigginton, M. J. 1973. Diffusion of oxygen through lenticels in potato tuber. Potato Res. 16:85-87.

41. Wilson, C. R. 2001. Variability within clones of potato cv. Russet Burbank to infection and severity of common scab disease of potato. J. Phytopathol. 149:625-628

42. Wilson, C. R. 2004. A summary of common scab disease of potato research from Australia. Pages 198-232 in: Proc. Int. Potato Scab Sympos. (IPSS 2004), 6-7 September 2004, Sapporo, Japan. S. Naito, N. Kondo, S. Akino, A Ogoshi, and F. Tanaka, eds. Hokkaido University, Sapporo, Japan.

43. Zhang, X. J., Wang, J. S., and Fang, Z. D. 1991. Mechanism of resistance in potato varieties to lenticel infection by soft rot Erwinia. Acta Phytopathol. Sinica 21:205-209. 